\title{
Supplementation of Lactobacillus casei reduces the mortality of Bombyx mori larvae challenged by Nosema bombycis
}

\author{
Siripuk Suraporn ${ }^{1}$ and Olle Terenius ${ }^{2^{*}}$ (1)
}

\begin{abstract}
Objective: Pebrine, caused by the microsporidium Nosema bombycis, is one of the severe diseases in Thai polyvoltine strains of the silkworm Bombyx mori. Studies showing the presence of Lactobacillus species in the silkworm gut, where the Nosema parasites enter, suggests that these bacteria may have a protective effect. The aim of this study was to investigate the effect of supplementation of Lactobacillus casei on the survival ratio of silkworm larvae challenged with N. bombycis.

Results: A group of silkworm larvae of the commercial Thai polyvoltine hybrid strain DokBua was supplemented with L. casei on the second day of the $2 \mathrm{nd}, 3 \mathrm{rd}, 4 \mathrm{th}$, and 5 th instar. When a control group of silkworm larvae were challenged with N. bombycis on the second day of the 4 th instar, the survival rate was $68 \%$, but it was $91 \%$ for larvae supplemented with L. casei. For those larvae that survived the treatments until pupation, we determined the growth characters larval weight, cocooning ratio, and pupation ratio, and the economic characters cocoon weight and cocoon shell weight. When infected with N. Bombycis, growth characters were significantly higher in larvae also receiving $L$. casei.
\end{abstract}

Keywords: Pebrine, Probiotic bacteria, Lactobacillus casei, Polyvoltine silkmoth, DokBua

\section{Introduction}

The microsporidium Nosema bombycis is an obligate intracellular parasite that causes pebrine disease in the silkworm Bombyx mori. N. bombycis can be transmitted both horizontally and vertically $[1,2]$. In horizontal transmission, the microsporidian spore is ingested by the silkworm larva through contaminated mulberry leaves and then germinates under alkaline conditions inside the larval midgut [3, 4]. The microsporidian spore sends out a polar tube, which penetrates the epithelial cell and surrounding muscles and spreads out to every part of the larval body. The sporoplasm

*Correspondence: olle.terenius@icm.uu.se

${ }^{2}$ Department of Cell and Molecular Biology, Uppsala University, Box 549,

75124 Uppsala, Sweden

Full list of author information is available at the end of the article multiplies by fission, spreads through the hemolymph and reaches every part of the silkworm body such as fat body, muscular tissue, silk gland, and reproductive system [5]. The spore completes its multiplication and life cycle within 4 days. The $N$. bombycis infection may be highly virulent resulting in heavy loss for sericulture practice or result in chronic infection [6]. However, pebrine disease may manifest itself in all stages. As a chronic infection, the infected silkworm larvae survive into the pupal and adult stages and the $N$. bombycis is then vertically transmitted to the eggs [2]. In larvae, the typical symptoms of pebrine are dark spots on the larval integument, and pale, dull, translucent and wrinkled skin $[7,8]$. The black spot symptom is a result of an increase of juvenile hormone during infection, which also leads to small larval size, delayed development and molting problems [9]. Highly

(c) The Author(s) 2021, corrected publication 2022. Open Access This article is licensed under a Creative Commons Attribution 4.0 International License, which permits use, sharing, adaptation, distribution and reproduction in any medium or format, as long as you give appropriate credit to the original author(s) and the source, provide a link to the Creative Commons licence, and indicate if changes were made. The images or other third party material in this article are included in the article's Creative Commons licence, unless indicated otherwise in a credit line to the material. If material is not included in the article's Creative Commons licence and your intended use is not permitted by statutory regulation or exceeds the permitted use, you will need to obtain permission directly from the copyright holder. To view a copy of this licence, visit http://creativecommons.org/licenses/by/4.0/. The Creative Commons Public Domain Dedication waiver (http://creativecommons.org/publicdomain/zero/1.0/) applies to the data made available in this article, unless otherwise stated in a credit line to the data. 
infected pupae fail to metamorphose into adult moths. Adults experience irregular moth emergence, clubbed wings and low fecundity. In the case of severe infection, non-hatching and dead eggs are observed. In the case of low infection, the eggs hatch and $N$. bombycis develops at the larval stage and causes death in the latter stages of larvae and in pupae. Since pebrine may be vertically transmitted, it is difficult to eliminate from the silkworm rearing. Instead, options for eliminating the pebrine outbreaks could be to select for tolerant silkworm strains, augment the immune response, or apply a treatment against the $N$. bombycis. One such treatment is application of probiotics and recent data indicate that Nosema infection is decreased in Lactobacillus-treated honey bees (Apis mellifera) $[10,11]$.

Probiotics used as supplementation have been shown to inhibit and reduce growth of pathogens, particularly in honey bees [12]. Probiotics also produce lactic acid, which decrease $\mathrm{pH}$ in the midgut, decrease populations of pathogens, reduce gut inflammation and increase immune function and overall gut health [13]. The most common probiotics used are bacteria in the genera Lactobacillus and Bifidobacterium. Lactobacillus is a genus of Gram-positive, non-sporulated and anaerobic bacteria with positive health effects on the gut [14]. Bermudez-Brito et al. [15] demonstrated and summarized six major mechanisms of action of probiotics: (1) enhancement of the epithelial barrier, (2) increased adhesion to intestinal mucosa, (3) inhibition of pathogen adhesion, (4) competitive exclusion of pathogenic microorganisms, (5) production of antimicroorganism substances, and (6) modulation of the immune system. In insects, honey bees are known to harbor several species of lactic acid-producing bacteria, which function as probiotics and induce the innate immune response [16]. In bivoltine B. mori, the innate immunity was stimulated by Lactococcus lactis [17] and by Lactobacillus paraplantarum [18]. Subramanian et al. [19] studied antibacterial activity and ecofriendly properties of the probiotic Streptomyces noursei for management of silkworm diseases. $S$. noursei increased the endogenous actinomycetes population in the silkworm strains PM and CSR2, but inhibited the growth of other Gram-positive and Gram-negative bacteria [19].

Recently, Yeruva et al. [20] used $16 \mathrm{~S}$ sequencing to investigate the presence of potential probiotics in $B$. mori and found that one of the dominating genera was Lactobacillus. We hypothesized that feeding Lactobacillus bacteria could reduce the number of dead silkworm larvae challenged by $N$. bombycis and found significant positive effects.

\section{Main text}

\section{Materials and methods Silkworm rearing}

The commercial Thai hybrid silkworm strain, DokBua was used. It is provided to Thai farmers because of its high silk yield. It also has a short life cycle, which results in a short time to obtain silk products. Moreover, it can be reared all year around because of being polyvoltine [21]. Eggs were provided by the Center of Excellence for Silk Innovation, Mahasarakham University (MSU), Thailand. Silkworm eggs were incubated at $25{ }^{\circ} \mathrm{C}$ for 8 days. After the egg color changed from yellow to dark gray, the egg surface was disinfected by soaking eggs into $3 \%$ formaldehyde solution for $10 \mathrm{~min}$. Then eggs were soaked in $75 \%$ ethylalcohol for $1 \mathrm{~min}$, followed by $1 \mathrm{~min}$ in $95 \%$ ethylalcohol. The eggs were then returned into the $25{ }^{\circ} \mathrm{C}$ incubator and incubation was continued until hatching. Newly hatched larvae of DokBua were reared by feeding on mulberry leaves harvested from the mulberry plantation in the experimental station at MSU under standard rearing conditions at $25-26{ }^{\circ} \mathrm{C}$ with relative humidity of $75-80 \%$. The silkworm larvae were fed on mulberry leaves only until they became second instar larvae. From the second instar larvae onwards, larvae were fed according to the feeding plans described in "Feeding experiments" below.

\section{Preparation of Nosema bombycis}

Pebrine-infected silkworm larvae were collected from silkworm household sericulturists in the Borabue village, Mahasarakham province, Thailand in May 2017. Spores of $N$. bombycis were propagated by oral inoculation of $3^{\text {rd }}$ larvae and isolated in the laboratory of MSU. Fifteen diseased larvae were crushed in distilled water and the crude extract was filtered through a fine muslin cloth. The filtrate was transferred into a centrifuge tube and centrifuged in a Sigma 6-16 Centrifuge (Sigma Laborzentrifugen $\mathrm{GmbH}$, Osterode am Harz, Germany) at $4340 \times g$ for $5 \mathrm{~min}$. The supernatant was discarded and the pellet was suspended in distilled water and washed three times. To confirm the presence of $N$. bombycis spores, the suspension was examined by phase contrast light microscopy at $400 \times$ magnification by the first author Siripuk Suraporn. The concentration of spores was counted with a hemocytometer by the first author Siripuk Suraporn. The N. bombycis spores were fed to the silkworm larvae at a concentration of $10^{6}$ spores $/ \mathrm{mL}$.

\section{Preparation of L. casei}

The Lactobacillus casei strain TISTR 1463 was provided from the Thailand Institute of Scientific and Technological Research (TISTR). Pure cultures were obtained by 
streaking out bacteria on Luria Broth (LB) agar $(2 \% \mathrm{NaCl}$; Difco, Lawrence, KS, USA) and incubated at room temperature overnight. A single colony was picked up and transferred into $10 \mathrm{~mL}$ of LB broth, supplemented with $2 \% \mathrm{NaCl}(\mathrm{w} / \mathrm{v})$ and incubated at $28^{\circ} \mathrm{C}$ overnight with agitation. The $L$. casei culture was transferred into $50 \mathrm{~mL}$ of Man, Rogosa, Sharpe (MRS; Difco, Lawrence, KS, USA) medium broth and incubated under the same conditions overnight. The culture broth was then centrifuged at $4340 \times g$ at $4{ }^{\circ} \mathrm{C}$ for $15 \mathrm{~min}$. The pellet of $L$. casei was collected and washed with distilled water. The concentration of the culture suspension used to feed the silkworm larvae $\left(10^{8}\right.$ bacteria $\left./ \mathrm{mL}\right)$ was determined by counting with a hemocytometer (Boeco, Hamburg, Germany).

\section{Feeding experiments}

To explore if $L$. casei had a protective effect on Nosema infection, $B$. mor $i$ larvae were fed on mulberry leaves cut in pieces of $2 \times 2 \mathrm{~cm}$ and dipped in L. casei $\left(10^{8}\right.$ bacteria/ $\mathrm{mL}$ ), followed by mulberry leaves dipped in $N$. bombycis $\left(10^{6}\right.$ spores $\left./ \mathrm{mL}\right)$. Three control treatments were set up: (1) larvae fed on mulberry leaves only, (2) larvae fed on mulberry leaves supplemented with $L$. casei $\left(10^{8}\right.$ bacte$\mathrm{ria} / \mathrm{mL}$ ), (3) larvae fed on mulberry leaves supplemented with $N$. bombycis $\left(10^{6}\right.$ spores $\left./ \mathrm{mL}\right)$. Two $\mathrm{mL}$ of $L$. casei or parasite solution were used per 100 larvae and the larvae consumed all solution provided. Mulberry leaves supplemented with $L$. casei were given on the second day after molting in the 2nd, 3rd, 4th and the 5th instar (thus at day 5, 8, 12 and 16). Mulberry leaves supplemented with $N$. bombycis spores were given on the second day after molting in the 4th instar. Each experiment was replicated three times with 25 silkworm larvae per replication. The number of deceased larvae were counted until the end of the 5th instar. Also measured were larval weight of the 5th instar, cocooning ratio, pupation ratio, cocoon weight, and cocoon shell weight. The data were analyzed using Duncan multiple range test at $95 \%$ confidence level with Statistica 4.3.

\section{Results}

\section{Pebrine infection}

Severely infected silkworm larvae had spotted markings, which could be seen within 8 days after infection (Fig. 1a). The larvae displayed unequal body size in the same instar due to retarded growth of diseased larvae (Fig. 1b). Other symptoms were slow motion and no feeding, which was observed 5 days after infection. $N$. bombycis spores in infected larvae were oval and reflective (Fig. 1c, d).

The feeding experiments resulted in a statistically significant difference in survival ratio for pebrine-infected larvae supplemented with $L$. casei $(91.00 \pm 0.57 \%)$ as compared to pebrine-infected larvae not receiving $L$.

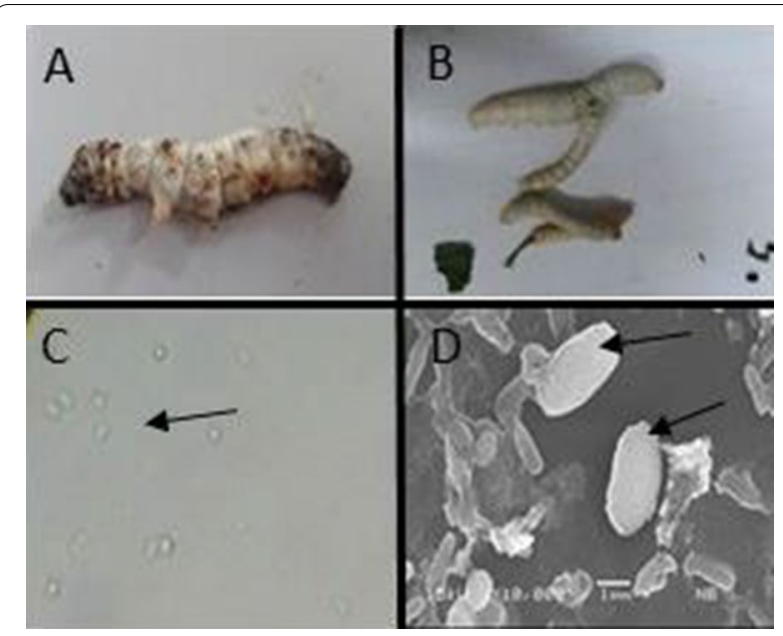

Fig. 1 The symptom of pebrine by Nosema bombycis, a so-called black pepper symptom found in the 5th instar larva, $\mathbf{b}$ size differences within the same instar, $\mathbf{c}, \mathbf{d}$ spores of Nosema bombycis observed under light microscope (40X magnification) and scanning electron microscope, respectively

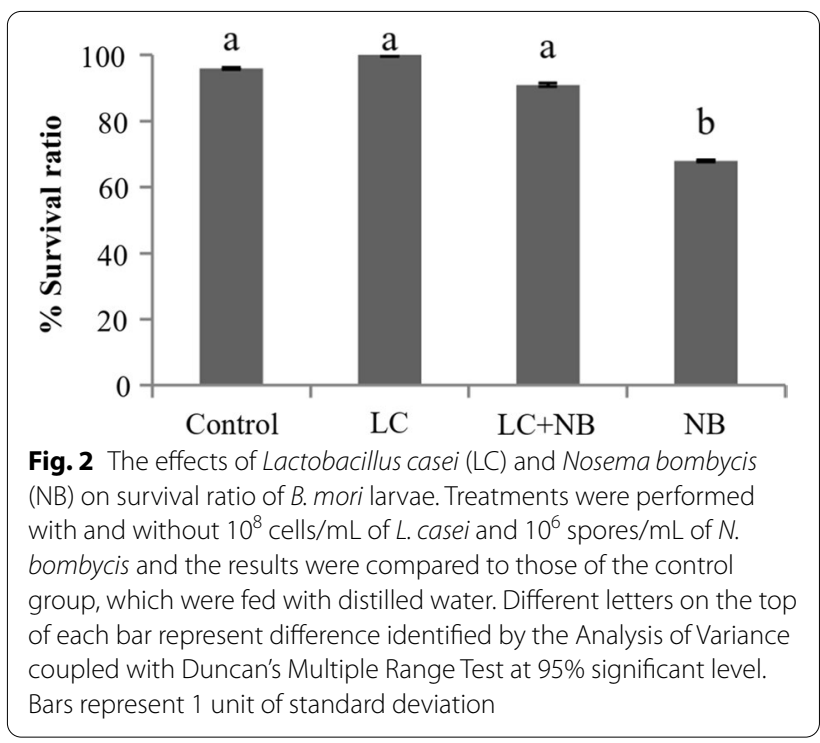

casei $(68.00 \pm 0.33 \%$; Fig. 2$)$. There was no statistical difference in survival ratio for silkworm larvae supplemented with L. casei $(100.00 \pm 0.33 \%)$, control larvae $(96.00 \pm 0.33)$, and larvae receiving both $L$. casei and $N$. bombycis $(91.00 \pm 0.33 \%)$. For the silkworm larvae surviving until pupation, growth characters such as larval weight of the 5th instar (g), cocooning ratio (\%), and pupation ratio (\%), and economic characters such as cocoon weight $(\mathrm{g})$ and cocoon shell weight $(\mathrm{g})$ were determined (Table 1). 
Table 1 Effects of Lactobacillus casei and Nosema bombycis challenge on Thai polyvoltine strain, DokBua, of the silkworm, Bombyx mori

\begin{tabular}{|c|c|c|c|c|c|}
\hline \multirow[t]{3}{*}{ Treatments $(n=75)$} & \multicolumn{5}{|c|}{ Quality parameter (means \pm SD) } \\
\hline & \multicolumn{3}{|c|}{ Growth characters } & \multicolumn{2}{|l|}{ Economic characters } \\
\hline & $\begin{array}{l}\text { Larval weight of } \\
5 \text { th instar }(g)\end{array}$ & Cocooning ratio (\%) & Pupation ratio (\%) & Cocoon weight (g) & $\begin{array}{l}\text { Cocoon shell } \\
\text { weight (g) }\end{array}$ \\
\hline $\begin{array}{l}\text { Lactobacillus casei }\left(10^{8} \text { cell } / \mathrm{mL}\right) \text { followed } \\
\text { by Nosema bombycis }\left(10^{6} \text { spores } / \mathrm{mL}\right)\end{array}$ & $2.70 \pm 0.96^{\mathrm{a}}$ & $95.00 \pm 0.00^{\mathrm{ab}}$ & $95.00 \pm 0.33^{\mathrm{a}}$ & $1.33 \pm 0.33^{\mathrm{a}}$ & $0.23 \pm 0.33^{\mathrm{a}}$ \\
\hline No treatment & $2.55 \pm 0.48^{\mathrm{a}}$ & $96.00 \pm 0.33^{b}$ & $100.00 \pm 0.33^{b}$ & $1.23 \pm 0.67^{\mathrm{a}}$ & $0.20 \pm 0.57^{\mathrm{a}}$ \\
\hline Lactobacillus casei (108 cells/mL) & $2.84 \pm 0.48^{\mathrm{a}}$ & $96.00 \pm 0.57^{b}$ & $100.00 \pm 0.57^{b}$ & $1.40 \pm 0.58^{\mathrm{a}}$ & $0.23 \pm 0.67^{\mathrm{a}}$ \\
\hline Nosema bombycis ( $10^{6}$ spores $/ \mathrm{mL}$ ) & $2.12 \pm 0.96^{b}$ & $93.00 \pm 0.33^{\mathrm{a}}$ & $87.00 \pm 0.66^{c}$ & $1.27 \pm 0.33^{\mathrm{a}}$ & $0.23 \pm 0.33^{\mathrm{a}}$ \\
\hline
\end{tabular}

Statistically significant differences as measured by Duncan multiple range test are denoted with different letters

The $L$. casei supplementation had positive impact on the growth characters (Table 1). As compared to larvae receiving only $N$. bombycis, the $5^{\text {th }}$ larval instar weight was significantly higher in all groups. $N$. bombycis infection significantly lowered the cocooning ratio, but $L$. casei treatment made the ratio remain on an intermediate level. The pupation ratio was $100 \%$ in the groups not infected by $N$. bombycis. The $L$. case $i$ treatment resulted in a significantly higher pupation ratio in $N$. bombycis-infected larvae (95\% with L. casei vs. $87 \%$ without $L$. case $i$ ). The highest cocoon weight and cocoon shell weight were obtained in those larvae receiving $L$. casei, although this difference was not statistically significant.

\section{Discussion}

A major problem for the silk production in Thailand is diseases of silkworm larvae. The microsporidian Nosema bombycis, which leads to the chronic disease pebrine, is a key pathogen for Thai polyvoltine silkworm strains and causes severe economic loss in sericulture. In this paper, we explored the possibility to treat Bombyx mori larvae with Lactobacillus casei to mitigate the effect of N. bombycis infection. Our study demonstrated that supplementation of $L$. casei at a concentration of $10^{8}$ bacteria/ $\mathrm{mL}$ made pebrine-infected silkworm larvae survive at the same level as non-infected larvae.

The midgut environment of the silkworm larva plays a major role in the resistance/tolerance or susceptibility to pathogens including $N$. bombycis. The highest germination of Nosema occurs at $\mathrm{pH} 9-10[6,22]$. Thus, the decrease in pebrine mortality in larvae treated with lactic acid bacteria could be related to a reduction of $\mathrm{pH}$ in the midgut, which possibly led to lowered infectivity of the spores. An alternative mechanism of action that could affect the $N$. bombycis infection might be a competitive adhesion of $L$. casei to the intestinal mucosa, which would inhibit pathogen adhesion. Potentially, modulation of the immune system by $L$. casei could lead to production of anti-microbial substances [17]. Indeed, Nishida et al. [12] demonstrated that the lactic acid bacteria Lactococcus lactis stimulated the innate immunity in silkworms.

We also showed that the $L$. casei treatment led to increased weight gain in the DokBua polyvoltine silkworm strain. Although not statistically different, the average weight of the 5th larval instar was higher in larvae receiving $L$. casei as compared to control. This was true also for $N$. bombycis-infected larvae receiving $L$. casei whereas infected larvae without $L$. casei treatment had a significant weight loss as compared to all other groups. Thus, the $L$. casei treatment seemed to increase food digestion and absorption of nutrients, which promoted growth characters. Similarly, Sekar et al. [23] studied the effect of several species of Bacillus and Lactobacillus on the growth parameters and cocoon production in B. mori by adding putative probiotic strains as supplementation with mulberry leaves. They found that $L$. casei enhanced length and weight of the larval body, and significantly increased silkworm cocoon weight. Alternatively, or in addition, $L$. casei may have increased the protection against harmful bacteria, thus potentially leading to resource allocation towards growth rather than immune response.

\section{Limitations}

This is a preliminary proof-of-principle showing that supplementation of Lactobacillus results in reduced mortality for silkworm larvae challenged by Nosema bombycis. Further studies are needed to elucidate the role and mechanism of this effect and to optimize the application of bacteria. For example, is the protective effect caused by a lower $\mathrm{pH}$, and if so, for how long does it remain after supplementation of bacteria? May the microsporidian gene expression be affected by the presence of $L$. casei? Will treatment with Lactobacillus lead to complete extermination of microsporidia, or may a fraction remain that in 
turn could cause vertical transmission by surviving pupae? While the study shows an effect on $N$. bombycis that has been orally infected, there is also a vertical transmission of these parasites, does the supplementation of $L$. casei have any effect on vertically transmitted microsporidia? How much bacteria are needed and when should they be applied for optimal results?

This preliminary study has been conducted with only one concentration of bacteria and one concentration of Nosema. It has also focused on one strain of bacteria, parasite and host. Changing any of these five parameters may change the outcome.

\section{Abbreviations}

MSU: Mahasarakham University; TISTR: Thailand Institute of Scientific and Technological Research; LB: Luria Broth; MRS: Man, Rogosa, Sharpe.

\section{Acknowledgements}

We acknowledge the Center of Excellence for Silk Innovation, Mahasarakham University for providing silkworm eggs. We thank Dr. Aekapot Srifa for statistical analysis.

\section{Authors' contributions}

SS designed the study, performed the laboratory activities and analyzed the data. SS and OT wrote the manuscript. All authors read and approved the final manuscript.

\section{Funding}

This study was supported in part by the National Research Council of Thailand and a Swedish Research Links grant from the Swedish Research Council (Grant No: 2017-05463). The funders were not involved in the design of the study and collection, analysis, and interpretation of data and in writing the manuscript. Open access funding provided by Uppsala University.

\section{Availability of data and materials}

The datasets generated during and/or analyzed during the current study are available from the corresponding author on reasonable request.

\section{Declarations}

Ethics approval and consent to participate

Not applicable.

\section{Consent for publication}

Not applicable.

\section{Competing interests}

The authors declare that they have no competing interests.

\section{Author details}

${ }^{1}$ Department of Biology, Faculty of Science, Mahasarakham University, Tambon Khamriang, Kantaravichai District, Maha Sarakham 44150, Thailand. ${ }^{2}$ Department of Cell and Molecular Biology, Uppsala University, Box 549, 751 24 Uppsala, Sweden.

Received: 10 May 2021 Accepted: 11 October 2021

Published online: 26 October 2021

\section{References}

1. Bhat SA, Bashir I, Kamili AS. Microsporidiosis of silkworm, Bombyx mori L. (Lepidoptera-Bombycidae): a review. Afr J Agric Res. 2009;4:1519-23. https://doi.org/10.5897/AJAR.9000490.

2. Han MS, Watanabe H. Transovarial transmission of two microsporidia in the silkworm, Bombyx mori, and disease occurrence in the progeny population. J Invertebr Pathol. 1988;51:41-5. https://doi.org/10.1016/ 0022-2011(88)90086-9.

3. Peter A, Sadatulla F, Devaiah MC. The viral, bacterial and protozoan diseases of the silkworm, Bombyx mori L. In: Devaiah MC, Narayanaswamy KC, Maribashetty VG, editors. Advance in mulberry sericulture. Bangalore: C.V.G. publications; 1999. p. 378-457.

4. Franzen C. How do microsporidia invade cells? Folia Parasitol. 2005;52:3640. https://doi.org/10.14411/fp.2005.005.

5. Fujiwara T. Microsporidia from silkworm moths in egg production sericulture. J Seric Sci. 1985;54:108-11. https://doi.org/10.11416/jibs.72.1.

6. Singh T, Bhat MM, Khan MA. Microsporidiosis in the silkworm, Bombyx mori L. (Lepidoptera: Bombycidae). Pertanika J Trop Agric Sci. 2012;35:387-406 (ISSN 1991-637X).

7. Singh T, Saratchandra B. Microsporidian disease of the silkworm, Bombyx mori L. (Lepidoptera: Bombycidae). Int J Indust Entomol. 2003;6:1-9.

8. Solter LF, Becnel JJ, Oi DH. Microsporidian Entomopathogens. In: Vega FE, Kaya HK, editors. Insect pathology (second editor). London: Academic Press; 2012.

9. Szumowski SC, Troemel R. Microsporidia-host interactions. Curr Opin Microbiol. 2015;26:10-6. https://doi.org/10.1016/j.mib.2015.03.006.

10. Arredondo D, Castelli L, Porrini MP, Garrido PM, Eguaras MJ, Zunino P, Antúnez K. Lactobacillus kunkeei strains decreased the infection by honey bee pathogens Paenibacillus larvae and Nosema ceranae. Benef Microbes. 2018;9:279-90. https://doi.org/10.3920/BM2017.0075.

11. Tejerina MR, Benítez-Ahrendts MR, Audisio MC. Lactobacillus salivarius A3iob reduces the incidence of Varroa destructor and Nosema spp. in commercial apiaries located in the northwest of Argentina. Probiot Antimicrob Proteins. 2020;12:1360-9. https://doi.org/10.1007/ s12602-020-09638-7.

12. Nishida S, Ono Y, Sekimizu K. Lactic acid bacteria activating immunity improve survival in bacterial infection model of silkworm. Drug Discov Ther. 2016;10:49-56. https://doi.org/10.5582/ddt.2016.01022.

13. Nishida S, Nishiya Y, Abe S, Ono Y, Sekimizu K. Lactobacillus paraplantarum 11-1 isolate from rice bran pickles activated innate immunity and improved survival in a silkworm bacterial infection model. Front Microbiol. 2017:8:1-8. https://doi.org/10.3389/fmicb.2017.00436.

14. Hamdi C, Balloi A, Essanaa J, Crotti E, Gonella E, Raddadi N, Ricci I, Boudabous A, Borin S, Manino A, Bandi C, Alma A, Daffonchio D, Cherif A. Gut microbiome dysbiosis and honey bee health. J Appl Entomol. 2011;135:524-33. https://doi.org/10.1111/j.1439-0418.2010.01609.x.

15. Ramos OY, Basualdo M, Libonatti C, Vega MF. Current status and application of lactic acid bacteria in animal production systems with a focus on bacteria from honey bee colonies. J Appl Microbiol. 2020;128:1248-60. https://doi.org/10.1111/jam.14469.

16. Walker WA. Mechanism of action of probiotics. Clin Infect Dis (CID). 2008. https://doi.org/10.1086/523335.

17. Bermudez-Brito M, Diaz JP, Quezada SM, Llorente CG, Gil A. Probiotic mechanisms of action. Ann Nutr Metab. 2012;61:160-74. https://doi.org/ $10.1159 / 000342079$.

18. Evans JD, Lopez DL. Bacterial probiotics induce and immune response in the honey bee (Hymenoptera:Apidae). J Econ Entomol. 2004;97:752-6. https://doi.org/10.1603/0022-0493(2004)097[0752:bpiair]2.0.co;2.

19. Subramanian S, Mohanrag P, Muthuswamy M. New paradigm in silkworm disease management using probiotic application of Streptomyces noursei. Karnataka J of Agric Sci. 2009;22:499-501 (ISSN: 0972-1061).

20. Yeruva T, Vankadara S, Ramasamy S, Lingaiah K. Identification of potential probiotics in the midgut of mulberry silkworm, Bombyx mori through metagenomic approach. Probiot Antimicrob Proteins. 2020;12:635-40. https://doi.org/10.1007/s12602-019-09580-3. 
21. The Queen Sirikit Department of Sericulture. The Thai hybrid silkworm rearing in Thailand. In: Proceeding of the 24 th congress on sericulture and silk industry, Bangkok, Thailand, 10-14 August 2016; 2016.

22. Undeen AH, Epsky ND. In vitro and in vivo germination of Nosema locustae (Microspora: Nosematidae) spores. J Invert Pathol. 1990;56:371-9. https://doi.org/10.1007/s12602-019-09580-3.

23. Sekar P, Kalpana S, Ganga S, John G, Kannadasan N. Effect of the probionts to the enhancement of silk proteins (sericin and fribroin) in the silk gland and cocoons of silkworm (LxCSR2) Bombyx mori (L.). Int J Pharm Biol Sci. 2016;11:19-25. https://doi.org/10.9790/3008-11030219.

\section{Publisher's Note}

Springer Nature remains neutral with regard to jurisdictional claims in published maps and institutional affiliations.
Ready to submit your research? Choose BMC and benefit from:

- fast, convenient online submission

- thorough peer review by experienced researchers in your field

- rapid publication on acceptance

- support for research data, including large and complex data types

- gold Open Access which fosters wider collaboration and increased citations

- maximum visibility for your research: over $100 \mathrm{M}$ website views per year

At BMC, research is always in progress.

Learn more biomedcentral.com/submissions 